\title{
Questes
}

vestes Revue pluridisciplinaire d'études médiévales

\section{Les bruits des villes et les bruits des champs}

\section{Nelly Labere}

\section{(2) OpenEdition}

\section{Journals}

\section{Édition électronique}

URL : http://journals.openedition.org/questes/2324

DOI : 10.4000 /questes.2324

ISSN : 2109-9472

\section{Éditeur}

Les Amis de Questes

\section{Édition imprimée}

Date de publication : 15 mars 2003

Pagination : 8-9

ISSN : 2102-7188

\section{Référence électronique}

Nelly Labere, «Les bruits des villes et les bruits des champs », Questes [En ligne], 3 | 2003, mis en ligne le 01 janvier 2014, consulté le 19 septembre 2020. URL : http://journals.openedition.org/questes/2324 ; DOI : https://doi.org/10.4000/questes.2324

Ce document a été généré automatiquement le 19 septembre 2020.

(C) Association des amis de «Questes » 


\title{
Les bruits des villes et les bruits des champs
}

\author{
Nelly Labere
}

NOTE DE L'ÉDITEUR

Cet article n'a pas encore fait l'objet d'une autorisation de publication.

INDEX

Keywords : noise, city, countryside, shout, rumour, rumbling, voice, woman, memory, language Mots-clés : bruit, ville, campagne, cri, rumeur, voix, femme, mémoire, langage 